\title{
BAURAN PEMASARAN JASA DALAM MEMPENGARUHI KEPUASAN PENGGUNA JASA HOTEL DI DEPOK
}

\author{
Oleh:
}

Rukiah

Grahawita Santika Hotel1)

rukiah1234@gmail.com1)

\begin{abstract}
ABSTRAK
Tujuan penelitian adalah untuk mengetahui pengaruh bauran pemasaran jasa yang terdiri dari produk, harga, promosi, lokasi, orang, proses dan bukti fisik terhadap kepuasan pengguna jasa hotel di Depok.

Pengumpulan data dilakukan langsung dengan mengajukan kuesioner kepada para tamu hotel di kota Depok. Santika Premiere Jakarta. Sample yang dipilih adalah sebanyak 100 tamu hotel sebagai responden yang diambil secara acak.

Hasil penelitian menghasilkan model yang layak untuk menjelaskan pengaruh bauran pemasaran jasa terhadap kepuasan. Model penelitian menunjukkan bahwa produk, harga, promosi, lokasi, orang, proses, dan bukti fisik mampu menjelaskan 65,5\% variasi kepuasan. Hanya variable Produk dan Promosi yang berpengaruh terhadap kepuasan sementara Harga, Lokasi, Orang, Proses, dan Bukti Fisik tidak berpengaruh terhadap Kepuasan.

Kata kunci:

Bauran pemasaran jasa, Produk, Harga, Promosi, Lokasi, Orang, Proses, Bukti fisik, Kepuasan

\section{PENDAHULUAN}

Pada era globalisasi saat ini, persaingan bisnis perhotelan semakin bertambah ketat. Hal ini menuntut para pelaku pengusaha perhotelan untuk mampu memaksimalkan kinerja perusahaan agar dapat bersaing dalam industri perhotelan. Manajemen Hotel Santika Premiere Jakarta berusaha keras untuk mempelajari dan memahami kebutuhan dan keinginan pelanggannya agar dapat menciptakan kepuasan.

Kepuasan pelanggan telah menjadi konsep sentral dalam wacana bisnis dan manajemen. Kepuasan merupakan salah

satu dari kegiatan pokok perusahaan dalam usahanya untuk mempertahankan kelangsungan hidupnya, untuk berkembang dan mendapatkan laba.

Pelanggan umumnya mengharapkan produk berupa barang atau jasa yang dikonsumsi dapat diterima dan dinikmatinya dengan pelayanan yang baik atau memuaskan. Pelayanan yang baik akan memberikan kepuasan kepada pelanggannya. Kepuasan dapat membentuk persepsi dan hal ini dapat memposisikan produk perusahaan di mata pelanggannya. Hal tersebut penting sebagai acuan dalam pembenahan kualitas
\end{abstract}


pelayanan, sehingga pelayanan yang diberikan bisa memberikan kepuasan pada tingkat yang optimal.

Kepuasan pelanggan merupakan tujuan yang ingin dicapai perusahaan dalam kegiatan pemasaran. Banyak hal yang dapat menyebabkan kepuasan pelanggan. Salah satu hal terpenting dalam kegiatan pemasaran yang dapat mendorong kepuasan pelanggan adalah pelaksanaan bauran pemasaran. Bauran pemasaran dalam industry jasa seperti perhotelan dikenal dengan bauran pemasaran jasa yang terdiri dari Produk, Harga, Promosi, Lokasi, Orang, Proses dan Physical Evidence.

Perusahaan yang mampu bersaing dalam pasar adalah perusahaan yang dapat menyediakan produk atau jasa berkualitas. Suka tidak suka manajemen hotel dituntut untuk selalu melakukan kreasi, salah satunya dengan memberikan produk yang baik sesuai dengan harapan konsumen pada umumnya. Fasilitas dan layanan merupakan produk yang dimiliki oleh hotel. Jika Fasilitas dan layanan tidak sesuai dengan selera konsumen maka beresiko kegagalan mendapatkan laba maksimal dan berpalingnya para konsumen ke hotel lain.

Harga adalah salah satu unsur berikutnya dalam bauran pemasaran. Harga merupakan faktor utama yang dipertimbangkan oleh konsumen dalam memilih produk ataupun jasa. Penentuan harga yang tepat dengan pasar sasaran akan mendatangkan kepuasan bagi pelanggan sebagai pasar sasaran.

Promosi menjadi langkah berikutnya untuk mengenalkan keseluruhan yang dimiliki perusahaan. Promosi yang tidak sesuai dengan pangsa pasar berakibat siasia. Promosi diharapkan menjadi sebuah strategi pemasaran yang efektif dalam menarik minat konsumen.
Keunggulan letak diharapkan membuat para calon pelanggan tertarik memilih hotel sebagai tempat mereka menginap. Selain faktor tempat yang mudah dijangkau serta lokasi yang aman, pelayanan dari karyawan yang bernampilan rapih, profesional serta cepat tanggap terhadap kebutuhan pelanggan merupakan hal yang perlu diperhatikan. Para pelanggan akan sangat senang bila segala pelayanan yang diberikan cepat dan mudah didapatkan serta sesuai dengan harapan. Selain faktor manusia atau karyawan hotel, kemudahan dalam berbagai pelayanan yang diharapkan juga merupakan nilai lebih dari sebuah kualitas jasa sebuah hotel. Proses check in dan check out yang mudah sangat membantu pelanggan yang mempunyai kesibukan sangat tinggi dan waktu yang relatif sedikit.

Kekuatan bersaing bagi suatu usaha perhotelan ini adalah kesanggupannya untuk mengungguli hotel lainnya dalam memperoleh pangsa pasar. Dalam persepsi konsumen, kekuatan bersaing adalah daya tarik terhadap produk atau jasa yang bisa membuat mereka memilihnya diantara banyak produk atau jasa yang tersedia, dan diantara komponen daya tarik dalam persepsi pelanggan tersebut adalah lingkungan fisik atau Physical Evidence dari tempat jasa disampaikan.

Physical Evidence merupakan salah satu unsur bauran pemasaran yang mempunyai arti penting bagi suatu usaha jasa untuk mencapai tujuan perusahaan yaitu kepuasan konsumen. Kepuasan konsumen yang meningkat kemudian akan mendatangkan keuntungan yang terus - menerus karena konsumen tersebut loyal terhadap produk atau jasa yang kita jual atau tawarkan. Dengan mengelola kinerja Physical Evidence dengan baik maka kita bisa menciptakan citra yang baik bagi perusahaan kita. Sehingga akan 
muncul citra positif yang akhirnya membuat pelanggan itu loyal terhadap produk jasa yang ditawarkan.

\section{TUJUAN PENELITIAN}

Untuk mengetahui pengaruh bauran pemasaran jasa yang terdiri dari produk, harga, promosi, lokasi, orang, proses dan bukti fisik terhadap kepuasan pengguna jasa hotel di Depok.

\section{TELAAH LITERATUR DAN PENGEMBANGAN HIPOTESIS \\ Literatur \\ Pemasaran Jasa}

Pemasaran jasa tidak sama dengan pemasaran produk. Pemasaran jasa lebih bersifat intangible dan immaterial karena produknya tidak kasat mata dan tidak dapat diraba (Rangkuti, 2009). Dalam pemasaran jasa, ada elemen lain yang bisa dikontrol dan dikoordinasikan untuk keperluan komunikasi dengan pemuasan konsumen jasa, yaitu: orang (people or participants) lingkungan fisik di mana jasa diberikan atau bukti fisik (physical evidence), dan proses (process) jasa itu sendiri (Yazid, 2001).

Jasa memiliki empat karakteristik yang sangat mempengaruhi rancangan pemasaran, yaitu: intangibility, inseparability, variability, dan perishability (Kotler \& Keller, 2012 : 358). Karena ciri-ciri jasa tersebut, maka tugas membangun program pemasaran jasa yang terpadu dalam industri jasa benar-benar merupakan sebuah tantangan

\section{Bauran Pemasaran Jasa}

Bauran pemasaran merupakan seperangkat alat yang dapat digunakan pemasar untuk membentuk karakteristik jasa yang ditawarkan kepada pelanggan . (Kotler \& Keller, 2012). Bauran pemasaran jasa dapat juga digunakan untuk menyusun strategi jangka panjang serta merancang program taktik jangka pendek. Konsep bauran pemasaran pada awalnya hanya dirumuskan menjadi 4P (Product, Price, Promotion, and Place). Dalam pemasaran jasa konsep bauran pemasaran yang tradisional tersebut diperluas lagi dengan menambah 3 (tiga) unsur lagi lainnya, yaitu People, Process, Physical Evidence dan Customer Service. Dengan adanya penambahan ini maka karakteristik jasa lebih dapat dilihat dan dikaji secara lebih luas dalam menentukan strategi apa yang nantinya sesuai untuk digunakan dalam memenuhi kepuasan pelanggan.

Produk merupakan salah satu aspek penting dalam variabel bauran pemasaran, produk juga merupakan salah satu variabel yang menentukan dalam kegiatan suatu usaha. Produk adalah segala sesuatu yang dapat ditawarkan ke pasar untuk mendaptkan perhatian, dibeli, digunakan atau dikonsumsi yang dapat memuaskan keinginan dan kebutuhan (Kotler \& Keller, 2012). Produk yang ditawarkan meliputi barang fisik, jasa, orang/pribadi, tempat, organisasi, dan ide. Jadi produk dapat berupa tangible maupun intangible yang dapat memuaskan pelanggan.

Keputusan bauran harga berkenaan dengan kebijakan strategis dan taktis, seperti tingkat harga, struktur diskon, syarat pembayaran, dan tingkat diskriminasi harga di antara berbagai kelompok pelanggan. Harga adalah jumlah uang (satuan moneter) dan/atau aspek lain (non moneter) yang mengandung utilitas/kegunaan tertentu yang diperlukan untuk mendapatkan suatu jasa (Fandy Tjiptono, 2008). Harga memainkan peran yang penting dalam bauran pemasaran jasa, karena penetapan harga memberikan penghasilan bagi bisnis (Payne, 2001) 
Promosi adalah kegiatan yang mengkomunikasikan jasa produk dan menganjurkan pelanggan sasaran untuk membelinya (Kotler \& Keller, 2012). Kegiatan promosi dilakukan untuk mencapai berbagai tujuan: 1) Menciptakan atau meningkatkan awarenes produk atau brand. 2) Meningkatkan preferensi brand pada target pasar. 3) Meningkatkan penjualan dan market share 4) Mendorong pembelian ulang merek yang sama. 5) Memperkenalkan produk baru 6) Menarik pelanggan baru (Hasan, 2008).

Lokasi (place) dalam service merupakan gabungan antara lokasi dan keputusan atas saluran distribusi. Lokasi berkenaan dengan keputusan perusahaan mengenai di mana operasi dan stafnya akan ditempatkan (Payne, 2000) Faktor tempat/distribusi yang terdapat dalam pemasaran jasa terdiri dari: jenis saluran, perantara, lokasi outlet, transportasi, penyimpanan dan mengelola (Zeithaml dan Bitner, 2001).

Proses produksi merupakan faktor yang penting bagi konsumen jasa, karena dalam perusahaan jasa cara melayani dan waktu yang dibutuhkan pelanggan untuk mendapatkan pelayanan akan menentukan kepuasan pelanggan nantinya. Dalam manajemen jasa dan manajemen operasi terkait erat dan sulit dibedakan dengan tegas.

Proses merupakan gabungan semua aktivitas yang terdiri dari prosedur, jadwal pekerjaan, aktivitas dan hal-hal rutin, dimana jasa dihasilkan dan disampaikan kepada konsumen (Lupiyoadi, 2006). Proses dapat dibedakan dalam 2 (dua) cara, yaitu: 1) Complexity, hal ini berhubungan dengan langkah dan tahap dalam proses. 2) Divergence, berhubungan dengan adanya perubahan dalam langkah atau tahap proses.

Orang merupakan unsur vital dalam bauran pemasaran jasa, oleh karena itu setiap perusahaan harus dapat memperhatikan para karyawan dengan baik melalui standarisasi dalam perusahaan, karena dalam perusahaan jasa kualitas dari karyawan adalah menjadi nilai tambah yang dapat membedakan kualitas jasa yang diberikan oleh pesaingnya. Orang (people) adalah semua pelaku yang memainkan sebagian penyajian jasa dan karenanya mempengaruhi persepsi pembeli (Yazid, 2005). Espek people yang mempengaruhi konsumen, yaitu peran contactor, modifiers, influencers, dan isolaters (Lupiyoadi, 2006).

Lingkungan fisik merupakan elemen substansif dalam konsep jasa. Bukti fisik merupakan lingkungan fisik perusahaan jasa di mana layanan diciptakan dan di mana penyedia jasa dan pelanggan berinteraksi, ditambah unsur-unsur berwujud yang ada dan dipakai untuk berkomunikasi atau mendukung peran jasa (Payne, 2000). Lingkungan fisik tempat jasa diciptakan dan langsung berinteraksi dengan konsumen dapat dibagi dua tipe physical evidence, yaitu esensial evidence dan peripheral evidence.

\section{Kepuasan}

Kepuasan konsumen adalah tingkat perasaan konsumen setelah membandingkan dengan harapannya (Husein Umar, 2005: 50). Seorang pelanggan jika merasa puas dengan nilai yang diberikan oleh produk atau jasa maka sangat besar kemungkinannya untuk menjadi pelanggan dalam waktu yang lama. Kepuasan konsumen juga dapat diartikan sebagai tingkat perasaan seseorang setelah membandingkan antara kinerja produk yang ia rasakan dengan harapannya (Kotler \& Keller, 2012).

Zeithaml dan Bitner (2001: 93) mengemukakan bahwa kepuasan 
konsumen dipengaruhi oleh beberapa faktor berikut:

a. Kualitas pelayanan; kualitas pelayanan sangat bergantung pada tiga hal, yaitu sistem, teknologi dan manusia. Kualitas pelayanan memiliki lima dimensi yaitu, keandalan (reliability), responsif (responsiveness), keyakinan (assurance), berwujud (tangibles), dan empati (empathy).

b. Kualitas Produk; Konsumen puas jika setelah membeli dan menggunakan produk, ternyata kualitas produknya baik. Ada delapan elemen dari kualitas produk, yakni kinerja, fitur, reliabilitas, daya tahan, pelayanan, estetika, sesuai dengan spesifikasi, dan kualitas penerimaan.

c. Harga

Pembeli biasanya memandang harga sebagai indikator dari kualitas suatu produk. Konsumen cenderung menggunakan harga sebagai dasar menduga kualitas produk. Maka konsumen cenderung berasumsi bahwa harga yang lebih tinggi mewakili kualitas yang tinggi.

d. Faktor situasi dan personal

Faktor situasi atau lingkungan dan pribadi, mempengaruhi tingkat kepuasan seseorang terhadap barang atau jasa yang dikonsumsinya. Faktor situasi seperti kondisi dan pengalaman akan menuntut konsumen untuk datang kepada suatu penyedia barang atau jasa, hal ini akan mempengaruhi harapan terhadap barang atau jasa yang akan dikonsumsinya. Efek yang sama terjadi karena pengaruh faktor personal seperti emosi konsumen.

\section{Kerangka Pemikiran}

Setiap strategi pemasaran yang dilakukan oleh perusahaan bertujuan untuk meningkatkan penjualan dari produk atau jasa. Bauran Pemasaran merupakan suatu komponen penting yang dapat mempengaruhi berhasil atau tidaknya suatu perusahaan. Oleh karena itu Bauran Pemesaran Jasa yang terdiri dari 7P yaitu Produk, Harga, Promosi, Lokasi, Orang, Proses dan Bukti fisik yang digunakan harus tepat dan efisien sehingga tujuan perusahaan tercapai.

Lupiyoadi (2006) menyatakan bahwa "Elemen marketing mix services strategic (strategi bauran pemasaran jasa) memiliki tujuh faktor dalam menetapkan keputusan pembelian oleh konsumen yaitu product, price, promotion, place, people, process, dan physical evidence ". Selanjutnya Lupiyoadi (2006) menyatakan bahwa "sebagai suatu bauran pemasaran, elemen tersebut (produk, harga, promosi, tempat, orang, proses, bukti fisik) saling mempengaruhi satu sama lain sehingga bila salah satu tidak tepat pengorganisasiannya akan mempengaruhi strategi pemasaran secara keseluruhan". Kotler \& Keller (2012), menyatakan bahwa "Serangkaian variabel pemasaran terkendali yang dipakai oleh perusahaan untuk menghasilkan tanggapan yang dikendalikan perusahaan dari pasar sasarannya, bauran pemasaran terdiri dari segala hal yang bisa dilakukan perusahaan untuk mempengaruhi permintaan atas produknya dikenal sebagai "empat $\mathrm{P}$ " yaitu produk (product), harga (price), tempat (place) dan promosi (promotion)". Tetapi dalam pemasaran jasa konsep bauran pemasaran yang tradisional tersebut diperluas lagi dengan menambah 3 (tiga) unsur lagi lainnya, yaitu People, Process, Physical Evidence dan Customer Service. Dengan adanya penambahan ini maka karakteristik jasa lebih dapat dilihat dan dikaji secara lebih luas dalam menentukan strategi apa yang nantinya sesuai untuk digunakan dalam memenuhi kepuasan pelanggan. 
Menurut Kuswadi (2004), menyatakan bahwa "Kepuasan pelanggan yaitu perbedaan antara harapan pelanggan dan persepsi pelanggan terhadap apa yang diberikan perusahaan. Selanjutnya menurut Irawan (2004), menyatakan bahwa "Kepuasan pelanggan ditentukan oleh persepsi konsumen atas performance jasa dalam memenuhi harapan pelanggan. Konsumen merasa puas apabila harapannya terpenuhi atau akan sangat puas jika harapan konsumen terlampaui". Menurut Zeithaml dan Bitner (2001: 75) definisi kepuasan adalah: Respon atau tanggapan konsumen mengenai pemenuhan kebutuhan. Kepuasan merupakan penilaian mengenai ciri atau keistimewaan produk atau jasa, atau produk itu sendiri, yang menyediakan tingkat kesenangan konsumen berkaitan dengan pemenuhan kebutuhan konsumsi konsumen.

Penelitian yang dilakukan oleh Putri (2012) menghasilkan temuan adanya pengaruh Bauran Pemasaran (produk, harga, lokasi, promosi) terhadap kepuasan pelanggan. Demikian juga hasil penelitian yang dilakukan oleh Rezeki (2008) dimana Bauran Pemasaran Berpengaruh Terhadap Keputusan Mahasiswa Memilih Sekolah Tinggi Ilmu Ekonomi (STIE) IBBI Medan. Temuan yang hampir sama terdapat pada penelitian Faizul (2008), dimana produk, harga, lokasi, orang dan pelayanan berpengaruh terhadap kepuasan dengan harga dan pelayanan menjadi factor dominan sedangkan variabel promosi dan proses tidak berpengaruh terhadap kepuasan.

Para ahli diantaranya Kotler \& Keller (2012) dan Lupioadi (2006) mengenai Bauran Pemasaran dan Kuswasdi (2004), Irawan (2004) serta Zeithaml dan Bitner (2001: 75) mengenai kepuasan dan hasil penelitian terdahulu yang dilakukan oleh Putri (2012), Rezeki (2008), Faizul (2008), maka diduga terdapat pengaruh Bauran pemasaran jasa terhadap kepuasan pelanggan.

Gambar 1

Kerangka Pemikiran

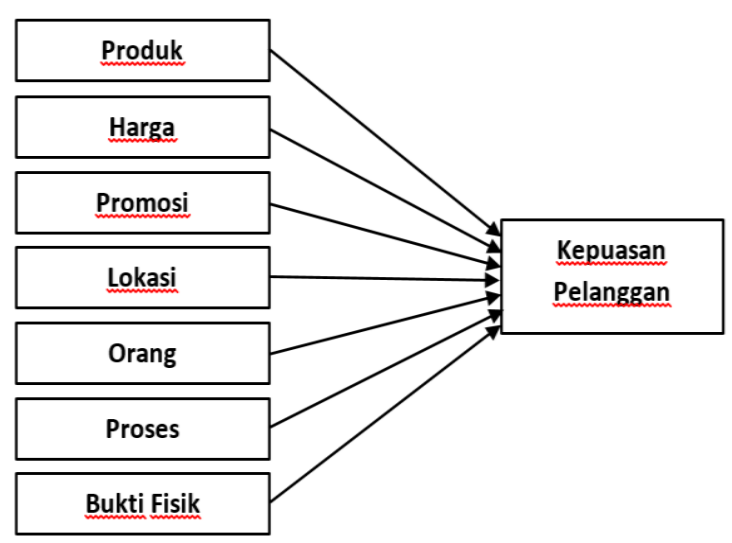

\section{METODE PENELITIAN}

\section{Tempat Penelitian}

Penelitian dilakukan di kota Depok selama 3 (tiga) bulan. Subyek penelitian adalah tamu hotel yang ada di Kota Depok.

\section{Operasionalisasi Variabel}

Tabel 1

Operasionalisasi Variabel

\begin{tabular}{|c|c|}
\hline Variabel & Indikator \\
\hline $\begin{array}{l}\text { Produk (product) adalah segala sesuatu yang dapat ditawarkan } \\
\text { produsen untuk diperhatikan, diminta, dicari, dibeli, digunakan } \\
\text { atau dikonsumsi pasar sebagai pemenuhan kebutuhan atau } \\
\text { keinginan (Kotler dan Armstrong, 2010:253) }\end{array}$ & $\begin{array}{l}\text { - Kenyamanan } \\
\text { - Kebersihan } \\
\text { - Fasilitas }\end{array}$ \\
\hline $\begin{array}{l}\text { Harga (Price) adalah jumlah uang (moneter) dan/atau aspek lain } \\
\text { (non moneter) yang mengandung utilitas/kegunaan tertentu yang } \\
\text { diperlukan untuk mendapatkan suatu jasa (Fandy Tjiptono, 2008). }\end{array}$ & $\begin{array}{l}\text { - Kesesuaian } \\
\text { - Daya saing } \\
\text { - Variasi }\end{array}$ \\
\hline $\begin{array}{l}\text { Promosi (Promotion) adalah komunikasi dari penjual dan pembeli } \\
\text { untuk merubah sikap dan tingkah laku pembeli, dari belum kenal } \\
\text { menjadi pembeli dan mengingat produk (Laksana, 2008: 133). }\end{array}$ & $\begin{array}{l}\text { - Iklan } \\
\text { - Promosi } \\
\text { - Personal Selling }\end{array}$ \\
\hline $\begin{array}{l}\text { Lokasi (Place) berkenaan dengan keputusan perusahaan mengenai } \\
\text { di mana operasi dan stafnya akan ditempatkan Payne (2000). }\end{array}$ & $\begin{array}{l}\text { - Akses } \\
\text { - Keamanan } \\
\text { - Lalulintas }\end{array}$ \\
\hline $\begin{array}{l}\text { Orang (people) adalah semua pelaku yang memainkan sebagian } \\
\text { penyajian jasa dan karenanya mempengaruhi persepsi pembeli. } \\
\text { (Yazid, 2005) }\end{array}$ & $\begin{array}{l}\text { - Keramahan } \\
\text { - Kerapihan } \\
\text { - Kemampuan }\end{array}$ \\
\hline $\begin{array}{l}\text { Proses (process) adalah gabungan semua aktivitas yang terdiri dari } \\
\text { prosedur, jadwal pekerjaan, aktivitas dan hal-hal rutin, dimana jasa } \\
\text { dihasilkan dan disampaikan kepada konsumen. (Lupiyoadi, 2006) }\end{array}$ & $\begin{array}{l}\text { - Reservasi } \\
\text { - Check in dan check out } \\
\text { - Kecepatan respon }\end{array}$ \\
\hline $\begin{array}{l}\text { Lingkungan fisik merupakan elemen substansif dalam konsep jasa. } \\
\text { Oleh karena itu para pemasar jasa semestinya terlibat dalam proses } \\
\text { desain, perencanaan, dan pengawasan bukti fisik (Yazid, 2001) }\end{array}$ & $\begin{array}{l}\text { - Kondisi Gedung } \\
\text { - Desain Interior } \\
\text { Fasilitas Fisik }\end{array}$ \\
\hline $\begin{array}{l}\text { Kepuasan Konsumen adalah merupakan tingkat perasaan } \\
\text { seseorang setelah membandingkan antara kinerja produk yang ia } \\
\text { rasakan dengan harapannya (Kotler, 2000:69) }\end{array}$ & $\begin{array}{l}\text { - Kesesuaian } \\
\text { - Kebanggaan } \\
\text { - Kedekatan }\end{array}$ \\
\hline
\end{tabular}




\section{Sampel Penelitian}

Penelitian

dilakukan dengan

mengambil 100 tamu hotel di Kota Depok. Pengambilan sampel dilakukan dengan metode accidental sampling.

\section{Metode Pengumpulan Data}

Data penelitian diperoleh melalui observasi dan penyebaran kuesioner. Observasi dilakukan dengan pengamatan langsung di beberapa hotel yang ada di Kota Depok. Penyebaran kuesioner dilakukan dengan memberikan lembaran kuesioner yang berisi pernyataan tertutup 7 skala penilaian kepada 100 responden yaitu tamu hotel di kota Depok.

\section{Metode Analisis}

Analisis data penelitian dilakukan dengan analisis regresi linier ganda (Mulyanto dan Wulandari, 2010). Analisis regresi linier ganda berupaya membukatikan ada tidaknya pengaruh Produk (X1), Harga (X2), Promosi (X3), Lokasi (X4), Orang (X5), Proses (X6), dan Bukti Fisik (X7) terhadap variable Kepuasan (Y). Analisis regresi linier ganda berturut-turut dilakukan dengan:

- Uji Persyaratan Analisis meliputi: uji normalitas, homogenitas, multikolinieritas, dan autokorelasi.

- Uji Kelayakan Model meliputi analisis koefisien determinasi menggunakan adjusted $\mathrm{R}$ Square dan pengujian kelayakan model dengan uji-F.

- Uji Hipotesis dilakukan dengan model persamaan regresi linier ganda dan uji t. Model persamaan regresi linier ganda yang terbentuk adalah $\mathrm{Y}=\mathrm{a}+$ $\mathrm{b} 1 \mathrm{X} 1+\mathrm{b} 2 \mathrm{X} 2+\mathrm{b} 3 \mathrm{X} 3+\mathrm{b} 4 \mathrm{X} 4+\mathrm{b} 5 \mathrm{X} 5+$ $\mathrm{b} 6 \mathrm{X6}+\mathrm{b} 7 \mathrm{X7}$. Adanya pengaruh ditunjukkan oleh nilai koefisien regresi bi dan pengaruhnya signifikan jika probabilitas penelitian (Sig. t) lebih kecil dari taraf uji penelitian $(\alpha)$.

\section{HASIL DAN PEMBAHASAN}

Hasil Penelitian

\section{Uji Persyaratan Analisis}

Kolmogorov-Smirnov test normalitas variable $\mathrm{X} 1, \mathrm{X} 2, \mathrm{X} 3, \mathrm{X} 4, \mathrm{X} 5, \mathrm{X} 6, \mathrm{X} 7$ terhadap variable $Y$ menghasilkan nilai Asmp. Sig adalah 0,073 lebih besar dari 0,05 maka data berdistribusi normal (persyaratan normalitas terpenuhi).

Test of Homogeneity of Variances variable $\mathrm{X} 1, \mathrm{X} 2, \mathrm{X} 3, \mathrm{X} 4, \mathrm{X} 5, \mathrm{X} 6, \mathrm{X} 7$ terhadap variable $Y$ menghasilkan nilai probabilitas (Sig.) untuk $\mathrm{X} 1=0,745 ; \mathrm{X} 2=0,194 ; \mathrm{X} 3=$ 0,$410 ; X 4=0,885 ; X 5=0,763 ; X 6=0,759 ; X 7$ $=0,622$ lebih besar daripada taraf uji penelitian $(\alpha=0,05)$ sehingga varian seluruh variable adalah identic (persyaratan homogenitas terpenuhi)

Nilai tolerance X1, X2, X3, X4, X5, X6, $X 7$ berturut-turut adalah $0.598 ; 0.941 ; 0.618$; $0.896 ; 0.891 ; 0.937 ; 0.964$ atau seluruhnya lebih besar dari 0.20. Nilai VIF X1, X2, X3, X4, X5, X6, X7 berturut-turut adalah 1.672; $1.063 ; 1.618 ; 1.116 ; 1.122 ; 1.067 ; 1.037$ atau seluruhnya lebih kecil dari 10,00. Hal ini menunjukkan tidak terjadi multikolinieritas (persyaratan multikolinieritas terpenuhi).

Nilai DW 1.506 dibandingkan dengan nilai tabel signifikansi 5\%, jumlah sampel 100 (n) dan jumlah variabel independen 7 $(\mathrm{K}=7)=7 ; 100$ maka diperoleh nilai $\mathrm{DW}$ 1,506 terletak diantara nilai dl 1,528 dan du 1,826 serta $(4-d w)=2,494$ terletak diantara $(4-\mathrm{dl})=2.472$ dan $(4-\mathrm{du})=2,174$, maka tidak menghasilkan kesimpulan yang pasti. Karena tidak ada kesimpulan yang pasti maka diasumsikan bahwa permasalahan autokorelasi tidak terjadi (persyaratan autokorelasi terpenuhi).

\section{Uji Kelayakan Model}

Analisis regresi linier ganda menghasilkan nilai koefisien determinasi: 
Tabel 2

Model Summary Analisis Regresi Linier Ganda Variabel X1 s.d X7 Terhadap Y

\begin{tabular}{|l|c|r|r|r|}
\hline \multicolumn{5}{|c|}{ Model Summary $^{\mathrm{b}}$} \\
\hline Model & R & R Square & Adjusted R Square & Std. Error of the Estimate \\
\hline 1 & $.825^{2}$ & .680 & .655 & 1.36707 \\
\hline
\end{tabular}

a. Predictors: (Constant), Bukti Fisik (X7), Proses (X6), Promosi (X3), Lokasi (X4), Harga (X2), Orang (X5), Produk (X1)

b. Dependent Variable: Kepuasan Pelanggan (Y)

Sumber: Data penelitian yang diolah, 2017

Nilai koefisien korelasi $\mathrm{R}=0,825$ terletak antara 0.800 - 1.000 kategori hubungan Sangat Kuat. Sedangkan koefisien determinasi yang disesuaiakan (Adjusted R Squre $=0,655$ ) menyatakan kontribusi variable indenpenden $(X 1, X 2$, X3, X4, X5, X6, X7) dalam menjelaskan variabilitas variable dependen $Y$ sebesar $65.5 \%$.

Tabel 3

Anova Analisis Regresi Linier Ganda Variable X1 s.d X7 Terhadap Y

\begin{tabular}{|c|c|c|c|c|c|}
\hline \multicolumn{6}{|c|}{ ANOVA $^{b}$} \\
\hline Model & $\begin{array}{l}\text { Sum of } \\
\text { Squares }\end{array}$ & $\mathrm{df}$ & Mean Square & $\mathrm{F}$ & Sig. \\
\hline $1 \quad$ Regression & 365.063 & 7 & 52.152 & 27.905 & $.000^{\mathrm{a}}$ \\
\hline Residual & 171.937 & 92 & 1.869 & & \\
\hline Total & 537.000 & 99 & & & \\
\hline
\end{tabular}

a. Predictors: (Constant), Bukti Fisik (X7), Proses (X6), Promosi (X3), Lokasi (X4), Harga (X2), Orang (X5), Produk (X1)

b. Dependent Variable: Kepuasan Pelanggan (Y)

Sumber: Data penelitian yang diolah, 2017

Adjusted R Square 0,373 memiliki nilai F-hitung = 27,905 dan probabilitas F hitung sebesar Sig. $F=0,000$. Karena Fhitung regresi lebih besar dari Ftabel (27.905 > $2,20)$ dan probabilitas regresi lebih kecil dari taraf uji penelitian $(0,000<0.05)$, pengaruh produk, harga, promosi, lokasi, orang, poses dan bukti fisik terhadap kepuasan adalah signifikan.

\section{Analisis Regresi Linier Ganda}

Model persamaan regresi linier ganda diperoleh dari table berikut:
Tabel 4

Coefficients Analisis Regresi Linier Ganda Variabel X1 s.d X7 Terhadap Y

\begin{tabular}{|c|c|c|c|c|c|c|}
\hline \multicolumn{7}{|c|}{ Coefficients $^{\mathrm{a}}$} \\
\hline & & \multicolumn{2}{|c|}{$\begin{array}{c}\text { Unstandardized } \\
\text { Coefficients } \\
\end{array}$} & \multirow{2}{*}{$\begin{array}{c}\begin{array}{c}\text { Standardized } \\
\text { Coefficients }\end{array} \\
\text { Beta }\end{array}$} & \multirow[b]{2}{*}{$t$} & \multirow[b]{2}{*}{ Sig. } \\
\hline \multicolumn{2}{|c|}{ Model } & B & Std. Error & & & \\
\hline 1 & (Constant) & 4.194 & 4.470 & & .938 & .351 \\
\hline & Produk (X1) & .352 & .079 & .339 & 4.448 & .000 \\
\hline & Harga (X2) & -.037 & .112 & -.020 & -.334 & .739 \\
\hline & Promosi (X3) & .541 & .073 & .560 & 7.464 & .000 \\
\hline & Lokasi (X4) & .048 & .085 & .035 & .569 & .571 \\
\hline & Orang (X5) & -.070 & .097 & -.045 & -.724 & .471 \\
\hline & Proses (X6) & .019 & .089 & .013 & .214 & .831 \\
\hline & Bukti Fisik (X7) & -.076 & .078 & -.059 & -981 & .329 \\
\hline
\end{tabular}

Sumber: Data penelitian yang diolah, 2017

Model persamaan regresi linier ganda hasil penelitian adalah:

$\hat{Y}=0,339 X 1-0.020 X 2+0,560 X 3+0,035 X 4$ $-0,045 \times 5+0,013 \times 6-0,059 \times 7$

Uji hipotesis berdasarkan table di atas:

1. T hitung untuk $X 1$ sebesar $4.448>t$ table (1.9858) dan probabilitas X1 $(0.000)<$ taraf signifikansi 0.05 berarti tidak signifikan, maka terdapat pengaruh signifikan antara produk terhadap kepuasan pelanggan.

2. Thitung untuk $X 2$ sebesar $-0,334<t$ table (-1.9858) dan probabilitas $\mathrm{X} 2$ $(0,739)>$ taraf signifikansi 0.05 yang berarti tidak signifikan, maka tidak terdapat pengaruh harga terhadap kepuasan.

3. Thitung untuk X3 sebesar 7.464 > t table (1.9858) dan probabilitas X3 $(0.000)<$ taraf signifikansi 0.05 , berarti signifikan, maka terdapat pengaruh signifikan antara promosi terhadap kepuasan pelanggan.

4. Thitung untuk X4 sebesar $0.569<\mathrm{t}$ table (1.9858) dan probabilitas $X 4$ $(0,571)>$ taraf signifikansi 0.05 yang berarti tidak signifikan, maka tidak terdapat pengaruh Lokasi terhadap kepuasan pelanggan. 
5. Thitung untuk X5 sebesar $-0.724<t$ table $(-1.9858)$ dan probabilitas $\times 5$ $(0,471)>$ taraf signifikansi 0.05 yang berarti tidak signifikan, maka tidak terdapat pengaruh orang terhadap kepuasan..

6. Thitung untuk $X 6$ sebesar $0.214<t$ table (1.9858) dan probabilitas X6 $(0,831)>$ taraf signifikansi 0.05 yang berarti tidak signifikan, maka tidak terdapat pengaruh proses terhadap kepuasan pelanggan.

7. Thitung untuk X7 sebesar $-0.981<\mathrm{t}$ table $(-1.9858)$ dan probabilitas $X 7$ $(0,329)>$ taraf signifikansi 0.05 yang berarti tidak signifikan, maka tidak terdapat pengaruh bukti fisik terhadap kepuasan pelanggan.

\section{Pembahasan}

Penelitian ini melibatkan 100 orang responden pelanggan yang menggunakan jasa Hotel di kota Depok. Penelitian menghasilkan temuan bahwa model persamaan regresi linier ganda hasil penelitian $\hat{Y}=0,339 X 1-0.020 X 2+0,560 X 3$ $+0,035 X 4-0,045 X 5+0,013 \times 6-0,059$ X7 layak digunakan untuk menjelaskan pengaruh Produk (X1), Harga (X2), Promosi (X3), Lokasi (X4), Orang (X5), Proses (X6), dan Bukti Fisik (X7) terhadap variable Kepuasan (Y). Pada model tersebut Produk, Harga, Promosi, Lokasi, Orang, Proses, dan Bukti Fisik mampu menjelaskan 65,5\% variasi Kepuasan.

1. Produk berpengaruh terhadap kepuasan. Hasil penelitian ini sejalan dengan penelitian terdahulu oleh Faizul (2008), Rezeki (2008) dan Berlian Aminanti Suraya Putri (2012) yang menyatakan bahwa produk, berpengaruh signifikan terhadap kepuasan pelanggan.

2. Harga tidak berpengaruh terhadap kepuasan. Hasil penelitian ini membantah penelitian terdahulu oleh
Faizul (2008), Rezeki (2008) dan Berlian Aminanti Suraya Putri (2012) yang menyatakan bahwa harga, berpengaruh signifikan terhadap kepuasan pelanggan

3. Promosi berpengaruh terhadap kepuasan. Hasil penelitian ini membantah hasil penelitian terdahulu oleh Faizul (2008), namun sejalan dengan hasil penelitian terdahulu oleh Rezeki (2008) dan Berlian Aminanti Suraya Putri (2012) yang menyatakan bahwa promosi berpengaruh signifikan terhadap kepuasan pelanggan

4. Lokasi tidak berpengaruh terhadap kepuasan. Hasil penelitian ini membantah penelitian terdahulu yang dilakukan oleh Faizul (2008), juga hasil penelitian oleh Rezeki (2008) dan Berlian Aminanti Suraya Putri (2012) yaitu penelitian terbaru menunjukkan bahwa lokasi tidak berpengaruh signifikan terhadap kepuasan pelanggan

5. Orang tidak berpengaruh terhadap kepuasan pelanggan. Hasil penelitian ini membantah penelitian terdahulu oleh Faizul (2008) dan Rezeki (2008) yang menunjukkan bahwa orang berpengaruh signifikan terhadap kepuasan pelanggan.

6. Proses tidak berpengaruh terhadap kepuasan. Hasil penelitian ini mendukung penelitian terdahulu oleh Faizul (2008) dimana proses tidak berpengaruh signifikan terhadap kepuasan pelanggan. Tetapi penelitian ini tidak sejalan dengan hasil temuan Rezeki (2008) yang menyatakan bahwa proses berpengaruh signifikan terhadap kepuasan pelanggan.

7. Bukti fisik tidak berpengaruh terhadap kepuasan pelanggan. Hasil penelitian ini membantah penelitian terdahulu oleh Faizul (2008), dan juga penelitian 
terdahulu oleh Rezeki (2008) yang menyatakan bahwa bukti fisik berpengaruh signifikan terhadap kepuasan pelanggan

\section{KESIMPULAN}

1. Penelitian menghasilkan model yang layak untuk menjelaskan pengaruh bauran pemasaran jasa terhadap kepuasan dimana produk, harga, promosi, lokasi, orang, proses, dan bukti fisik mampu menjelaskan $65,5 \%$ variasi kepuasan.

2. Produk dan Promosi berpengaruh terhadap kepuasan dengan arah positif sementara Harga, Lokasi, Orang, Proses, dan Bukti Fisik tidak berpengaruh terhadap Kepuasan.

\section{SARAN}

1. Bauran pemasaran jasa penting untuk memuaskan pelanggan jasa perhotelan dimana produk dan promosi hendaknya lebih diutamakan dalam rangka meraih kepuasan pelanggan.

2. Kenyaman, kebersihan dan fasilitas hotel hendaknya dijaga dengan baik didukung dengan berbagai kegiatan promosi seperti iklan, pemberian souvenir dengan berbagai benefit

3. Perlu dilakukan penelitian lebih lanjut mengingat dalam penelitian ini banyak elemen bauran pemasaran jasa yang tidak mampu mempengaruhi kepuasan.

\section{DAFTAR PUSTAKA}

Berlian Aminanti Suraya Putri. 2012. "Pengaruh Bauran Pemasaran Terhadap Kepuasan Pelanggan
(Studi Kasus Pada Toko Busana Muslim Dannis Collection Pati)". Skripsi. Institut Agama Islam Negeri Walisongo Semarang Faizul, Ahmad. 2008. Pengauh Strategi Bauran Pemasaran Ritel Terhadap Kepuasan dan Hubungannya dengan Loyalitas Pelanggan Plaza Medan Fair di Medan. Tesis. Magister IImu Manajemen. Universitas Sumatera Utara Medan

Husein, Umar. (2005). Riset pemasaran dan Perilaku komsumen. Cetakan Keempat. PT Gramedia Pustaka Utama, Jakarta.

Kotler, P.; Keller, KL. (2012). Marketing Management. 14th Edition. Pearson Education, New York

Lupiyoadi, R. (2006). Manajemen Pemasaran Jasa. Penerbit Salemba Empat, Jakarta.

Mulyanto, H.; Wulandari A. (2010). Penelitian: Metode \& Analisis. CV Agung, Semarang.

Rangkuti, F. (2009). Strategi Promosi yang Kreatif dan Analisis Kasus, Integrated Marketing Communication. PT Gramedia Pustaka Utama, Jakarta.

Rezeki, Sri. (2008). Analisis Pengaruh Bauran Pemasaran Terhadap Keputusan Mahasiswa Memilih Sekolah Tinggi llmu Ekonomi (Stie) Ibbi Medan.

Tjiptono F., (2014). Pemasaran Jasa: Prinsip, Penerapan dan Penelitian, Andi Publisher, Cetakan Kedua, ANDI, Yogyakarta.

Zeithaml, V.A. ; M.J. Bitner. (2001). Services Marketing : Integrating Customer Focus Across the Firm. International Edition. McGraw-Hill, United Statedof America 